\title{
Grzegorz Strauchold
}

\section{DZIAŁANIA APARATU BEZPIECZEŃSTWA WOBEC LUDNOŚCI NIEMIECKIEJ I TZW. AUTOCHTONÓW POLSKICH NA WARMII I MAZURACH W LATACH 1945-1956}

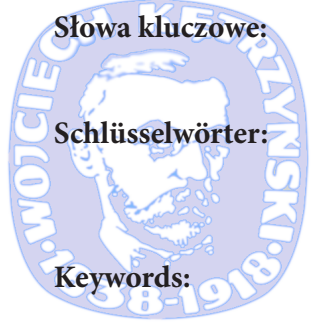

Ziemie Odzyskane, ludność niemiecka, autochtoni polscy, niemiecki rewizjonizm graniczny, emigracja do Niemiec

Wiedergewonnene Gebiete, deutsche Bevölkerung, polnische Autochthonen, deutscher Grenzrevisionismus, Emigration nach Deutschland

Recovered Territories, German population, Polish autochthonous, German border revisionism, emigration to Germany

Polska historia większej części byłych Prus Wschodnich rozpoczęła się w 1945 roku. To wówczas, obok sowieckich, okupacyjnych komendantur wojennych stopniowo instalowała się polska administracja. Z nią równolegle organy porządku i bezpieczeństwa uosabiane przez Milicję Obywatelską (w istocie policję) i Urzędy Bezpieczeństwa Publicznego (policję polityczną). Władze tak cywilne, jak i „siłowe” realizowały określoną politykę wobec zastanej na miejscu ludności, jak i wobec napływających osadników ${ }^{1}$. Strukturalnie obie gałęzie aparatu przymusu niemal bez zmian przetrwały do przemian wewnętrznych w Polsce 1956 roku. Wówczas to uległa przemianie - do pewnego stopnia - polityka prowadzona wobec zastanych na tych terenach obywateli niemieckich, zarówno rdzennych, etnicznych Niemców, jak i ludzi pochodzenia etnicznego polskiego.

\footnotetext{
1 Na ten temat w ostatnich dekadach narosła bogata literatura. Por. m. in.: A. Sakson, Mazurzy - społeczność pogranicza, Poznań 1990; G. Strauchold, Polska ludność rodzima ziem zachodnich i północnych. Opinie nie tylko publiczne lat 1944-1948, Olsztyn 1995; A. Sakson, Stosunki narodowościowe na Warmii i Mazurach 1945 1997, Poznań 1998; Z. Romanow, Polityka władz polskich wobec ludności rodzimej Ziem Zachodnich i Północnych w latach 1945-1960, Słupsk 1999; G. Strauchold, Autochtoni polscy, niemieccy, czy... Od nacjonalizmu do komunizmu (1945-1949), Toruń 2001; M. Hejger, Przekształcenia narodowościowe na Ziemiach Zachodnich i Pótnocnych Polski w latach 1945-1949, Słupsk 2008; A. Sakson, Od Kłajpedy do Olsztyna. Współcześni mieszkańcy byłych Prus wschodnich: Kraj Kłajpedzki, Obwód Kaliningradzki, Warmia i mazury, Poznań 2011; D. Krysiak, Warmia i Mazury w latach 1945-1950. Kształtowanie się stosunków politycznych i narodowościowych, Olsztyn-Białystok 2013.
} 
W latach 1945-1956 byłe ziemie wschodniopruskie włączone do Polski, zostały podzielone pomiędzy trzy województwa: gdańskie, olsztyńskie i białostockie. Niewielkie zmiany w granicach tych jednostek wprowadziła reforma administracyjna z 1950 roku. W niniejszym artykule skupiono się przede wszystkim na sytuacji w województwie olsztyńskim. W nim to bowiem zamieszkiwała zdecydowania większość ludności rodzimej (tzw. autochtonów polskich) - protestanccy Mazurzy i katoliccy Warmiacy. Na Powiślu (woj. gdańskie) i w białostockich powiatach Ełk, Gołdap, Olecko ludność rodzima występowała w niewielkiej ilości.

Szermująca w niezliczonych wypowiedziach oficjalna (ale nie tylko oficjalna) propaganda wskazywała na jakoby niezbywalne prawa historyczne, kulturalne i narodowościowe wobec tzw. Ziem Odzyskanych². W tym wobec polskiej części byłych Prus Wschodnich. W powodzi chciejstwa starano się wypracować stosunek czynników oficjalnych, ale i polskich osadników do zastanego dorobku cywilizacyjno-kulturalnego niemieckiej do niedawna krainy. Dla polskich wszelakich enúncjacji nie było wówczas możliwe - zresztą także jeszcze po kilku dekadach przywolywanie pierwiastków niemieckości w pozytywnym kształcie ${ }^{3}$. Próbowano wypreparować z nurtu rzeczywistej historii tych terenów jedynie wątki dające się wpisać w fenomen historii i tradycji polskiej. Tak materialnej, jak i ludzkiej. Refleksjom na temat tej polityki poświęcili swą niedawną twórczość tak uczeni niemieccy, jak i polscy ${ }^{4}$.

Były to zabiegi tyleż nienaturalne, ile niezbędne z punktu widzenia polityki pierwszych lat powojennych. Gdy równolegle - obok szykowania się przez władze państwowe do ideologicznego „skoku” na społeczeństwo - prowadzono zdecydowanie nacjonalistyczną politykę sekującą mniejszości narodowe (a szczególnie Niemców) i doszukującą się wszędzie na „Ziemiach Odzyskanych” pierwiastków polskości.

Była to polityka idąca „od góry”, tykająca się - w konsekwencji - wszelakiej zastanej na terenach poniemieckich ludności. Lecz najbardziej namacalna, realizowana natychmiast, w terenie, była „polityka” stosowana wobec miejscowych przez coraz liczniejszych osadników polskich. Spośród nich rekrutowali się administra-

2 Por. m. in.: J. Tyszkiewicz, Sto wielkich dni Wrocławia. Wystawa Ziem Odzyskanych we Wrocławiu a propaganda polityczna ziem zachodnich i pótnocnych w latach 1945-1948, Wrocław 1997; G. Strauchold, Myśl zachodnia i jej realizacja w Polsce Ludowej w latach 1945-1957, Toruń 2003; R. Domke, Ziemie Zachodnie i Pótnocne Polski w propagandzie lat 1945-1948, Zielona Góra 2010; G. Strauchold, Od Bieruta do Gierka. Ziemie zachodnie i pótnocne w optyce komunistycznej propagandy, [w:] Nad Odra i Bałtykiem. Myśl zachodnia: ludzie - koncepcje realizacja do 1989 r., red. M. Semczyszyn, T. Sikorski, A. Wątor, Szczecin 2013, ss. 471-488.

Por.: Polacy wobec Niemców. Z dziejów kultury politycznej Polski, red. A. Wolff-Powęska, Poznań 1993; Z. Mazur, O adaptacji niemieckiego dziedzictwa kulturowego na Ziemiach Zachodnich i Pólnocnych, Poznań 2001; Wspólne dziedzictwo? Ze studiów nad stosunkiem do spuścizny kulturowej na Ziemiach Zachodnich i Pólnocnych, red. Z. Mazur, Poznań 2000.

4 Por.: R. Traba, Kraina tysiąca granic. Szkice o historii i pamięci, Olsztyn 2003; A. Kossert, Mazury. Zapomniane południe Prus Wschodnich, Warszawa 2004; idem, Prusy Wschodnie. Historia i mit, Warszawa 2009. 
torzy i funkcjonariusze MO i UBP niższych szczebli. Co musiało rodzić - poza realizowaniem wskazań odgórnych - zjawisko, gdy „swój popierał swego”. Zjawisko tym bardziej groźne, gdy wiedza nie tylko „szeregowych” osadników i funkcjonariuszy, ale i „czynowników” wyższych stopni na temat miejscowych stosunków była jakże często bliska zeru. Nie mogły tego wyeliminować - w warunkach, gdy wszystko wówczas w Polsce było w nieustającym „ruchu” najbardziej nawet racjonalne koncepcje dotyczące akcji osadniczej ${ }^{5}$.

Zakładano, iż wszyscy (najlepiej bez wyjątku) Niemcy zostaną z terenów włączonych wysiedleni. By tego dokonać starano się w toku tzw. akcji weryfikacyjnej oddzielić od populacji deportowanej za Odrę ludzi, których uznano za Polaków. Akcja ta w województwie olsztyńskim poniosła spektakularną klęskę i to pomimo formalnego, pozytywnego stwierdzenia polskości - do 1 stycznia 1949 roku u około siedemdziesięciu tysięcy osób, przy blisko 34 tys. tzw. „niezdeklarowanych”. Sprawa owej "polskości” od początku była wysoce problematyczna. Po straszliwych okólicznościach zdobycia Prus Wschodnich przez Armię Czerwoną nadszedł czas rabunku, gwałtów i morderstw ze strony rajzujących na tereny wschodniopruskie mieszkańców przygranicznych terenów polskich. Tym bardziej uzasadniających swe postępowanie, iż faktycznie żywioł polski na protestanckich Mazurach był niemal niewidoczny. Nieco bardziej zaznaczony w południowej, katolickiej Warmii. Zatem szukający łatwej zdobyczy i powetowania sobie materialnych i moralnych strat wojennych Polacy zza przedwojennej granicy byli utwierdzani w słuszności swego postępowania. Gnębili Niemców, bo za takowych uważano - także pośród administracji, sił porząaku i bezpieczeństwa nie zawsze tylko najniższego szczebla - wszystkich, którzy pozostali na miejscu po ewakuacji i ucieczce ostatnich dni wojny $^{6}$. Sytuacja zdawała się dla przybywających tym bardziej wyrazista, iż gros ludności mazurskiej, zresztą porozumiewającej się przeważnie językiem niemieckim, była protestancka. Ustawiało to tę populację w opozycji do powstającej na tych terenach polskiej katolickiej administracji kościelnej

Zarządzone w dokumencie końcowym konferencji poczdamskiej przymusowe wysiedlenie Niemców z Polski w jej granicach (co ciekawe, bez wchodzenia w niuanse jej tymczasowego stanu granicznego na zachodzie i północy) rozpoczęło

5 Wśród najnowszej literatury na ten temat por.: C. Trosiak, Dyskusja na temat założeń i przebiegu polityki osadniczej na tzw. ziemiach odzyskanych w okresie II wojny światowej i bezpośrednio po jej zakończeniu, [w:] Nad Odrą, ss. 497-508.

6 Por.: G. Strauchold, Swoi czy obcy? Kwestia ludności autochtonicznej w pierwszych latach po zakończeniu II wojny światowej, [w:] Internacjonalizm czy...? Działania organów bezpieczeństwa państw komunistycznych wobec mniejszości narodowych (1944-1989), red. J. Hytrek-Hryciuk, G. Strauchold, J. Syrnyk, Warszawa-Wrocław 2011, ss. 77-91.

Por.: A. Kopiczko, Kościół warmiński a polityka wyznaniowa po II wojnie światowej, Olsztyn 1996; R. Michalak, Luteranie i metodyści na Mazurach 1945-1957. Wybór materiałów, Kraków 2000; idem, Kościoły protestanckie $i$ władze partyjno-państwowe w Polsce (1945-1956), Warszawa 2002. 
się w wielkiej skali na początku 1946 roku. Jednakże tzw. dzikie wysiedlenia rdzennej ludności wschodnich ziem niemieckich rozpoczęły się już na wiosnę 1945 roku, przybierając zresztą nierzadko drastyczne formy ${ }^{8}$. O czym naturalnie próżno szukać informacji w ówczesnych mediach. Więcej natomiast, nawet i z przytoczeniem drastycznych szczegółów można było (przynajmniej do 1947 roku) dowiedzieć się z periodyków na temat sytuacji tzw. autochtonów polskich. Pomimo, iż podlegały one ingerencjom cenzury ${ }^{9}$.

Odbiciem pełnych zaniepokojenia dokumentów tworzonych przez polską administrację były w jakimś stopniu enuncjacje prasowe. Konstatowano tu przerażające "nieprawidłowości” istniejące w realizowanej polityce wobec ludności rodzimej, która jako - jak zakładano - polska winna być przyciągana do narodu i państwa polskiego ${ }^{10}$. A przecież przez powojenne lata terroryzowana i na domiar przeważnie (Mazurzy) zniemczona, nie tylko nie wyrażała chęci integrowania się Z „takim” narodem polskim, ale nie kryła swych niemieckich przekonań narodowych. Albo przynajmniej swego pozytywnego stosunku do niemieckiej państwowósci, w której żyła - w jej mniemaniu - od zawsze. W której, co dla tych ludzi nierzadko było kluczowe, nie do pomyślenia było pozbawianie gmin ewangelickich majątku na rzecz instalującego się polskiego Kościoła katolickiego ${ }^{11}$. Trudno się zatem dziwić, że w dokumencie datowanym w grudniu 1945 roku napisano kilka gorzkich uwag o sytuacji ludności mazurskiej: „Mazurzy dotąd jeszcze uważani są za Niemców, napływowi urzędnicy i osadnicy nie rozumieją i nie doceniają wagi tego zagadnienia, stawiając Mazurów poza nawias życia. [...] Ludność Okręgu Mazurskiego, tak tubylcza [sic!], jak i napływowa, jest prawie całkowicie spauperyzowana". W dalszej części dokumentu wyłania się stan impotencji miejscowej polskiej administracji wobec rozpaczliwej sytuacji: „Okręg Mazurski należy do wyjątkowo zniszczonych, tak że [pisownia oryginalna - przyp. G.S.] sytuacja gospodarcza

8 Por.: B. Nitschke, Wysiedlenie ludności niemieckiej z Polski w latach 1945-1959, Zielona Góra 1999; Niemcy w Polsce 1945-1950. Wybór dokumentów, red. W. Borodziej, H. Lemberg, t. I, Władze i instytucje centralne. Województwo olsztyńskie, wyb. i oprac. W. Borodziej, C. Kraft, Warszawa 2000.

9 Por.: G. Strauchold, Polska ludność rodzima; idem, Ludność rodzima pod „opieką" cenzury (1945-1948). Przyczynek do polityki informacyjnej lat 40., [w:] Wrocławskie Studia z Historii Najnowszej, red. W. Wrzesiński, t. VIII, Wrocław 2001, ss. 277-286.

10 Por.: Archiwum Akt Nowych [dalej AAN], Ministerstwo Informacji i Propagandy [dalej MIP], sygn. 306 [mf. 28.208], „Ze sprawozdania miesięcznego, za sierpień, Urzędu Informacji i Propagandy przy Urzędzie Pełnomocnika Rządu Tymczasowego RP na Okręg Mazurski, dla Ministerstwa Informacji i Propagandy, o sytuacji polskiej ludności rodzimej, w tym pracach własnych w powiecie Szczytno, oraz przejściowym obozie jenieckim w Iławie” z 30 VIII 1945 r., k. 3-4; AAN, MIP, sygn. 140 [mf. 28042], „Sprawozdanie z działalności Ministerstwa Informacji i Propagandy za miesiąc wrzesień 1945 r.", k. 3; AAN, Ministerstwo Ziem Odzyskanych [dalej MZO], sygn. 60 [mf. B-5160], pismo z dn. 3 XI 1945 r. sygnowane przez Pełnomocnika Rządu na Okręg Mazurski pt. „Ekscesy maruderów zdemobilizowanej armii radzieckiej”, k. 4. Dokumenty tego typu można mnożyć.

11 Por.: AAN, Ministerstwo Administracji Publicznej [dalej MAP], sygn. 1053 [mf.B-2570], „Memoriał w sprawach Polskiego Kościoła Ewangelicko-Augsburskiego w R. P.” z dn. 12 X 1945 r. skierowany do premiera E. Osóbki-Morawskiego, k. 62-64; AAN, MAP, sygn. 943 [mf. B-1962], „Okólnik nr 55 w sprawie przekazywania majątków kościelnych" z 19 X 1945 r., k. 12-13. 
przedstawia się zgoła rozpaczliwie. Miejscowe władze administracyjne są bezsilne"12. Ta beznadziejna sytuacji, szczególnie na polu przestępczego (często zbrodniczego) traktowania ludności rodzimej, nie poprawiła się także w ciągu 1946 roku.

Zdać można sobie zatem sprawę, jak w takowych okolicznościach wyglądało ustosunkowanie się do ludności „niemieckiej” instytucji siłowych: MO, UBP i Wojska Polskiego. Z góry trzeba podkreślić, iż trudno w tym początkowym, gorącym okresie (przynajmniej do pierwszych miesięcy 1946 roku) doszukiwać się jakiejś manichejskiej gry Urzędów Bezpieczeństwa Publicznego wobec ludności miejscowej, podszytej celami stricte ideologicznymi. Tak miejscowi milicjanci (organicznie wszak powiązani z osadnikami), jak i funkcjonariusze UBP i żołnierze niemal niezmiennie traktowali „tubylców” jako Niemców jawnych, albo zakamuflowanych. Zatem stosunek ubeków do miejscowej ludności był elementem ogólnego stosunku do tej populacji ze strony - generalnie - Polaków przybywających na tereny „odzyskane”. Niezależnie, czy byli to „szeregowi” osadnicy, urzędnicy niższego szczebla, czy też milicjanci i żołnierze.

Ponieważ dla okresu sprzed 1948 roku niemal nie ma usystematyzowanych odnośnych archiwaliów resortowych dotyczących działalności pracowników bezpieki, kształt sytuacji daje się fragmentarycznie wydobyć z dokumentacji administracji cywilnej. Powstające w latach 1945-1946 (może nieco także w pierwszych miesiącach 1947 roku) dokumenty zawierały często szczere poglądy ich twórców wobec negatywnego, wprost przestępczego zachowania się milicjantów i żołnierzy w stosunku do ogółu miejscowej ludności, bez wchodzenia w niuanse pochodzenia etnicznego ${ }^{13}$. Stosunek „władz bezpieczeństwa” w relacjach z lata 1945 roku był $\mathrm{w}$ dokumentach cywilnych wskazywany jako „bardzo niepoprawny” ${ }^{14}$. Także w ciągu 1946 roku w kolejnych sprawozdaniach i pismach pojawiają się doniesienia o udziale pracowników UBP w przestępczej działalności uderzającej w ludność miejscową. Również tę będącą w trakcie postępowania weryfikacyjnego oraz już zweryfikowaną jako Polacy. Nadmienię, że w tamtejszych realiach nawet poświadczenie przedwojennej działalności w Związku Polaków w Niemczech nierzadko nie broniło jego posiadacza przed rabunkiem, represjami, brutalnym traktowaniem. Nawet działania podejmowane przez wojewódzką administrację dla ulżenia losu ludności uznawanej za polską bądź hipotetycznie polską były utrudniane. Na przykład poprzez ułatwianie przez „niektórych funkcjonariuszy” UBP rabowania Mazurów przez bandy szabrowników ${ }^{15}$.

12 AAN, MZO, sygn. 1081 [mf. B-6228], „Sprawozdanie Delegata Wojewódzkiego Biura Kontroli na Okręg Mazurski [...] dla dyrektora Biura Kontroli przy Prezydium Krajowej Rady Narodowej [...]., k. 41-46.

13 Por.: AAN, MIP, sygn. 307 [mf. 28.209], k. 15; AAN, MZO, sygn. 1076, k. 41-42; AAN, MZO, sygn. 60 [mf. B-5160], k. 153-156.

14 AAN, MIP, sygn. [mf.] 28. 548, k. 107.

15 Por.: AAN, MZO, sygn. 60 [mf. B-5160], pismo ministra [Ziem Odzyskanych?] do ministra Bezpie- 
Z ówczesnych dokumentów wyraźnie wyłaniała się jeszcze jedna prawidłowość. Zasadzająca się w dwuwładzy terenowej organów administracji państwowej i UBP. Właściwie winienem napisać o jedynowładzy, którą faktycznie sprawowali funkcjonariusze Ministerstwa Bezpieczeństwa Publicznego. W urzędowych dokumentach cywilnych niejednokrotnie podnoszono problem niereagowania UBP (i MO) na zgłaszane przestępstwa, czy też zagadnienie „braku odpowiedzialności służbowej organów Bezpieczeństwa Publicznego za obecny stan bandytyzmu”. Działo się tak mimo bezustannego pouczania przez administrację cywilną tych organów o konieczności zmiany nastawienia wobec miejscowej ludności ${ }^{16}$. Notabene w odnośnych dokumentach podkreślano troskę o ludność rodzimą. Nie ma w nich mowy o jakimś szczególnym zaniepokojeniu stosunkiem do pozostałej na miejscu ludności niemieckiej. Z góry przeznaczonej do wysiedlenia. Niemcy mieli podlegać ochronie przed jaskrawymi przestępstwami, ale nie byli oni grupą, na której by w jakiejkolwiek formie zależało polskim czynnikom oficjalnym.

W ciągu 1946 roku przedstawiciele administracji ogólnej podkreślali, że z Urzędami Bezpieczeństwa Publicznego w tych sprawach nie dawało się wspólpracowac. Jak napisano, „miejscowe organy bezpieczeństwa $\mathrm{z}$ reguły nie udzielały żadnych informacji, tłumacząc się brakiem odpowiednich w tej sprawie instrukcyj, względnie zasłaniając się przynależnością do Min. Bezp. Publicznego". Co więcej, starostowie obawiali się zwracać do UBP po jakiekolwiek informacje, by „nie dać powodu do wysoce niewłaściwych podejrzeń, a nawet oskarżeń” ${ }^{17}$. Należy uściślić, że dopiero w ciągu 1946 roku udało się centralnym władzom państwowym wyeliminować $\mathrm{z}$ administracji państwowej i samorządowej przedstawicieli opozycji politycznej, przede wszystkim wywodzących się z Polskiego Stronnictwa Ludowego ${ }^{18}$.

Pomimo zauważenia przeze mnie nieco powyżej braku jakiegoś szczególnego podejścia lokalnych UBP wobec traktowanej en bloc ludności miejscowej w pierwszych miesiącach polskiej władzy, to jednak w początkach 1946 roku sytuacja zaczęła się zmieniać, porządkować. Związane to było z planowanymi na najbliższe kilka miesięcy wielkimi kampaniami politycznymi. Dla legalnej opozycji miały być one

czeństwa Publicznego z 2 XI 1946 r., k. 186-188; AAN, MZO, sygn. 182 [mf. B-5286], sprawozdanie sytuacyjne wojewody olsztyńskiego Z. Robla za czerwiec 1946 r., k. 111-113.

16 Por.: AAN, MZO, sygn. 1081, k. 104-105; AAN, MZO, sygn. 60 [mf. B-5160], dokument z września 1946 r. w przedmiocie „zbadania przyczyn napadów, dokonywanych na ludność mazurską powiatu Szczytno przez ludność sąsiednich powiatów woj. warszawskiego", k. 168-172; AAN, MZO, sygn. 60 [mf. B-5160], notatka służbowa dla ministra Ziem Odzyskanych W. Gomułki, k. 189-192.

17 Por:: AAN, MZO, sygn. 1080, „Notatka służbowa do sprawozdań poinspekcyjnych w sprawie nadużyć w stosunku do ludności autochtonicznej w woj. olsztyńskim", k. 90-91; AAN, MZO, sygn. 60 [mf. B-5160], poufne pismo wojewody olsztyńskiego Z. Robla do Wojewódzkiego Komendanta MO z 13 sierpnia 1946 r., k. 153-156.

18 Por. na ten temat, jak również o zaangażowania PSL w prace wśród ludności rodzimej: B. Łukaszewicz, PSL na Warmii i Mazurach w latach 1945-1947, Warszawa 1996; T. Bańka, Ziemie odzyskane w polityce Polskiego Stronnictwa Ludowego w latach 1945-1947, [w:] Władze komunistyczne wobec Ziem Odzyskanych po II wojnie światowej, red. S. Łach, Słupsk 1997, ss. 113-121. 
zamanifestowaniem skali społecznego oporu wobec komunistów, dla drugiej strony barykady miały stanowić możliwość całkowitej rozprawy z legalną opozycją i okazję do wskazania narodowi, kto gra pierwsze skrzypce w Rzeczypospolitej. Zatem był to zbliżający się czas tzw. referendum ludowego (30 czerwca 1946 roku) i wyborów do Sejmu Ustawodawczego (19 stycznia 1947 roku). W planach centrum politycznego konkretną rolę miała mieć do spełnienia ludność rodzima. Bo Niemcom nikt praw wyborczych (no i oczywiście obywatelskich) nie zamierzał dawać ${ }^{19}$.

Było - z punktu widzenia celów wewnętrznych (integracja tzw. autochtonów polskich z narodem i państwem polskim) i zewnętrznych (oczekiwanie na konferencję pokojową, likwidującą poczdamskie prowizorium graniczne) - czym się martwić. Mazurzy, tylko w nieco mniejszym stopniu Warmiacy, mieli coraz bardziej dosyć zamieszkiwania w przerażającym dla nich państwie polskim. Także i ci pozytywnie zweryfikowani, a nawet weterani (nade wszystko Warmiacy) polskiego, przedwojennego ruchu mniejszościowego w Niemczech. Obrabowani, wygłodzeni, traktowani jak ludność bez prawa (bo tak tráktowano ogół ludności niemieckiej) nagminnie porzucali resztki ocalonego majątku i starali przedostać się do okupowanych Niemiec. Bardzo duże znaczenie miała tutaj także struktura tej ludności. Złożonej przede wszystkim ze starców (liczących na niemieckie, w końcu wypracowane całym życiem emerytury) oraz kobiet z dziećmi (nierzadko oczekujących na połączenie z mężami - żywicielami przebywającymi na Zachodzie, bo o tych znajdujących się w Związku Sowieckim niemal nic nie można się było dowiedzieć).

Trudno zatem było się dziwić, że wśród tej grupy ówczesnych mieszkańców Polski, mocno związanej - co wcześniej podkreśliłem - z narodowością albo co najmniej (i) z kulturą niemiecką - dawały się coraz wyraźniej widzieć proniemieckie nastroje. Budziło to zrozumiały niepokój w organach MBP. Nie tylko ze względu na narodowych charakter problemu, ale i - z coraz większą wagą - ze względu na nasilającą się „zimną wojnę” pomiędzy tyranią Wschodu a demokratycznym Zachodem. Sprawa niemiecka w tej półwiecznej (jak się okazało) rozgrywce odgrywała na kontynencie europejskim kluczową rolę.

Niepokój UBP „współgrał” na zasadzie przeciwieństw ze stosunkiem ludności miejscowej do komunistycznej policji politycznej. Jak napisał w październiku 1946 roku wojewoda olsztyński Robel (powiązany z opozycyjnym PSL) do wiceministra Ziem Odzyskanych Władysława Wolskiego [tak naprawdę nazywał się inaczej i pełnił zupełnie inną funkcję, nigdy też nie został oficjalnie mianowany owym wiceministrem-G.S.] „ludność autochtoniczna, całkowicie obrabowana

19 Por.: G. Strauchold, „Temperowanie” niepokornych. Komuniści wobec postaw wyborczych tzw. autochtonów polskich $w$ obliczu referendum (1946) i wyborów do sejmu Ustawodawczego (1947), [w:] Wybory i referenda w PRL, red. S. Ligarski, M. Siedziako, Szczecin 2014, ss. 581-595; idem, Trudne dziedzictwo. Wokół Kongresu Autochtonów w Warszawie (1946), [w:] Wspólne dziedzictwo?, ss. 483-514. 
i częstokroć jeszcze w dalszym ciągu krzywdzona przez nieodpowiedzialne jednostki organów bezpieczeństwa, a zwłaszcza MO, straciła wobec niemocy władz administracyjnych całkowicie zaufanie do władz i daje chętnie posłuch destrukcyjnej propagandzie szerzonej przez niemców [pis. oryg. - GS], jak również przez czynniki zagraniczne". W tymże piśmie, martwiąc się o stan umysłów ludności rodzimej, wojewoda apelował do Wolskiego, by ten wydał decyzję o „przyśpieszonej repatriacji najbardziej uciążliwych niemców [pis. oryg. - GS], jak starców, dzieci, ułomnych i niezdolnych do pracy..." ${ }^{20}$.

Jak wyżej podkreśliłem, w ciągu 1946 roku organa policji politycznej porządkowały swe sprawy i coraz bardziej systematycznie przystępowały do swej „statutowej” działalności. Między innymi produkowano charakterystyki ludności „warmijsko-mazurskiej”. Przykładowo we wrześniu 1946 roku Mazurzy z powiatu Kętrzyn (Rastembork) mieli być mało zaangażowani w życie publiczne, nieobjęci działalnością partii politycznych. Przyczyn tego stanu poszukiwano w nieznajomości języka polskiego wśród większości tejgrupy. Zauważano również nadal istniejące nadużycia wobec tej populacji $i^{21}$.

Sytuacja wśród tzw. ludności autochtonicznej nie ulegała pozytywnej zmianie także w kolejnych latach. Również z powodu nieustającej biedy. Zresztą, z góry zaznaczę, niewiele się zmieniło w stanowisku Mazurów (i częściowo Warmiaków) wobec narodowości i państwa polskiego także w następnych dekadach. Nie zmieniało się także - szczególnie wśród ogółu Mazurów - pozytywne nastawienie do niemieckości. Powodowało to nawiązywanie kontaktów (korespondencja, paczki) z krewnymi, znajomymi znajdującymi się zachodnich strefach okupacyjnych Niemiec, na których podstawie w 1949 roku utworzono demokratyczną Republikę Federalną Niemiec (zwaną w Polsce przez dekady Niemiecką Republiką Federalną). Skutkowało to przez kolejne dziesięciolecia wzmożonym zainteresowaniem wobec tej grupy ze strony komunistycznej policji politycznej.

Podobnie, w latach następnych nie ulegał jakiejś szczególnej zmianie stosunek do miejscowych ze strony polskich osadników. Nadal uważali oni ogół zastanej ludności za niemiecką $a^{22}$. Jeszcze przez długi czas owocowało to nadużyciami. Także w stosunku do ludności pozytywnie zweryfikowanej. Z zachowanych dokumentów administracyjnych w ciągu 1947 roku wyłaniała się zróżnicowana sytuacja tycząca

20 AAN, MZO, sygn. 68 [mf. B-5169], k. 90-91.

${ }^{21}$ Por.: Instytut Pamięci Narodowej, Oddział Białystok [dalej: IPN Bi], sygn. 087/162/jacket, k. 00020009; IPN Bi, sygn. 087/156/jacket, k. 0002-0030.

22 Sytuację tę scharakteryzował w okrągłych słowach w marcu 1947 r. wicewojewoda olsztyński: „Współżycie ludności napływowej z ludnością autochtoniczną na ogół jest dostateczne, jednak zdarzają się jeszcze wypadki, że ludność napływowa traktuje autochtonów jako niemców [pis. oryg. - GS]. W dużym stopniu przyczyną tego jest słaba znajomość języka polskiego wśród autochtonów, którzy dość często posługują się językiem niemieckim, ludność napływowa zaś będąc niejednokrotnie rozgoryczona z powodów utraty [zajętych uprzednio kosztem tzw. autochtonów - G.S.] posiadłości ziemskich (gospodarstw) na rzecz prawowitych właścicieli (autochtonów) [sta- 
się stosunków na linii państwo (i jego organy) - ludność rodzima. Wskazywano na skuteczność „organów bezpieczeństwa [które] panowały i wkraczały w przypadkach nadużyć", ale też (w innym dokumencie) nadal podkreślono brak dobrej (albo jakiejkolwiek) współpracy starostów z MO i UBP ${ }^{23}$. Niezmiennie o wszelkie wystąpienia przeciw polskiej władzy oskarżano „miejscowych” Niemców, wobec których - np. oskarżanych o celowe podpalanie lasów w powiecie Pisz - policja polityczna zastosowała „szereg aresztowań" ${ }^{24}$. Nie miały to być jedyne niepożądane zachowania miejscowej ludności. W raporcie dekadowym powiatowego UBP w Olsztynie z końca grudnia 1947 roku mowa była o postawach Warmiaków, generalnie „wrogo ustosunkowana do obecnego ustroju”. Miała wśród nich być szerzona propaganda o przyszłej zmianie granic Polski i o konieczności opuszczenia tego terenów przez polskich osadników ${ }^{25}$.

Poczynając od 1947 roku, w warunkach przyspieszającej ofensywy ideologicznej centrum politycznego państwa, doszło do administracyjnego, oficjalnego uznania wszelkich spraw trudnych na ziemiách zachodnich i północnych za rozwiązane. Owocowało to także powiększającym się brakiem zainteresowania kwestiamiludności rodzimej. Jej tematyka coraz rzadziej w latach 1947-1948 pojawiała się w wypowiedziach publicznych i w mediach. Do końca dekady lat 40. XX wieku zwinięto formy państwowej i społecznej (Polski Związek Zachodni) aktywności na polu integracji społecznej na terenach inkorporowanych w 1945 roku. Wszystko to w sytuacji, gdy rzeczywiste tamtejsze problemy były dalekie od pozytywnego rozwiązania ${ }^{26}$.

Szczególnie trudna sytuacja panowała na terenach mazurskich. Miejscowa ludność - nadal w masie słabo, albo w ogóle, nie władająca językiem polskim była niechętna akcji wersyfikacji narodowościowej. Jak wskazałem na początku artykułu, w początku 1949 roku, w zasadzie już po zakończeniu akcji weryfikacyjnej, poza jej zasięgiem pozostało kilkadziesiąt tysięcy ludzi. Nie chcieli się weryfikować, nie chcieli przyjąć obywatelstwa polskiego. Wobec takowej sytuacji - już niemal rok wcześniej, bo w lutym 1948 roku - wojewoda olsztyński W. Jaśkiewicz „dojrzał” do wniosku, iż niezakończenie selekcji narodowościowej w przewidzianym terminie może spowodować problem (nie do przyjęcia dla komunistów) konieczności „ewentl. wysiedlenia wielo-tysięcznej [pis. oryg. - GS] rzeszy opornych. Dlatego

rano się zwracać majątki pozytywnie zweryfikowanym - ale i ta akcja do końca się nie powiodła - G.S.], słysząc w dodatku mowę niemiecką, uważa tych ostatnich za niemców [pis. oryg. - G.S.] i częstokroć ustosunkowuje się do nich wrogo. Autochtoni zaś traktują przybyszów jako ludzi o niższej od nich kulturze”. Por.: AAN, MZO, sygn. [mf.] B-5293, k. 67.

23 Por.: AAN, MZO, sygn. 1082, k. 147; AAN, MZO, sygn. [mf.] B-5293, k. 60.

24 AAN, MZO, sygn. [mf.] B-5293, k. 80.

25 IPN Bi, sygn. 087/156/jacket, k. 0031-0032.

26 G. Strauchold, Zmierzch. Desinteressement komunistów wobec kwestii tzw. autochtonów polskich w końcu lat 40. XX w., Athenaeum. Polskie Studia Politologiczne, 2012, vol. 33, ss. 50-63. 
też w celu zapewnienia spokoju i bezpieczeństwa szczególnie na terenie powiatu szczycieńskiego zaszła konieczność zaprowadzenia pewnych pociągnięć i w tej sprawie porozumiałem się z Komendą Wojewódzką M.O.”27. Odnośne pismo, dość enigmatyczne, choć potencjalnie groźne, skierował do wiceministra Ziem Odzyskanych J. Dubiela. W sposób bezpośrednio jasny tenże wojewoda wypowiedział się tego samego dnia 20 lutego 1948 roku do starostów powiatowych. Napisał w nim expressis verbis, $\mathrm{iz}$ „[...] należycie zorganizowana akcja przyspieszonej weryfikacji wraz z zastosowaniem w wypadkach potrzeby środków represyjnych dla przełamania oporu, powinna dać [bardziej] pozytywne wyniki niż dotychczas. To też apeluję [...] do Ob. Ob. Starostów, by w tej tak doniosłej dla interesów państwowych akcji dołożyli wszelkich starań [...], gdyż problem ludności niezweryfikowanej, jako problem anachroniczny w dzisiejszej rzeczywistości [sic!] musi być w najkrótszym czasie zlikwidowany" ${ }^{28}$. Owo trwanie dużej ilości Mazurów w uporze próbowano sobie wówczas $\mathrm{w}$ sferach oficjalnych tłumaczyć. Wskazywano, że na ich postawy wpływa „całkowita dezorientacja” narodowościowa, koniunkturalizm w oczekiwaniu na ostateczne rozstrzygnięcia graniczne, niemiecka propaganda zewnętrzna obok wewnętrznej proniemieckiej propagandy szeptanej ${ }^{29}$. W jednej z trzeźwiejszych Z lata 1948 roku wypowiedzi - zresztą niepodpisanej - stwierdzono: „nie można zaprzeczyć, że Niemcom udało się, jeśli nie całkowicie zgermanizować, to w każdym razie znacznie od Polski i wszystkiego, co polskie oddalić znaczną część Mazurów, wśród których wybitnie przeważa orientacja niemiecka”30.

W związku z tą wysoce kryzysową sytuacją nastąpiła aktywizacja komunistycznej policji politycznej. W dość licznych dokumentach analizowano sprawę i wskazywano na przyczyny weryfikacyjnego zacięcia. W charakterystycznym spisie rozpracowywanych spraw powstałym w grudniu 1948 roku wymieniono: współpracę z obcym wywiadem; szeptaną propagandę; byłych agentów i konfidentów gestapo; byłych członków niemieckich organizacji pomocniczych; zebrania autochtonów; radiostacje nadawczo-odbiorcze ${ }^{31}$. W szeregu dokumentów szczegółowo wymieniono z imienia i nazwiska ludzi, wobec których wszczęto sprawy. Nadmienię, iż nie wszystkie dotyczyły ludności miejscowej. Wszak osadnicy także byli na celowniku bezpieki. Zarazem w zachowanych archiwaliach pojawiały się charakterystyki sieci agenturalnej (pseudonimy współpracowników) ${ }^{32}$. Zarazem w jednym

${ }_{27}$ AAN, MZO, sygn. [mf.] B-5607, k. 152.
AAN, MZO, sygn. [mf.] B-5607, k. 155.
${ }_{29}$ Por.: AAN, MZO, sygn. [mf.] B-5292, k. 44-45; AAN, MZO, sygn. [mf.] 5292, k. 146.
30 Archiwum Państwowe Poznań [dalej APP], Polski Związek Zachodni [dalej PZZ], sygn. 758, k. 19.
31 IPN Bi, sygn. 087/163/jacket, k. 0002.
Por. przykładowo: IPN Bi, sygn. 087/156/jacket, sygnowany przez Powiatowy Urząd Bezpieczeństwa Publicznego w Olsztynie „Raport sprawozdawczy z pracy Ref. I-go Sekc. I-ej za czas od 1.I.47 do 1.I.48”, k. 00380039 . 
z dokumentów z grudnia 1948 roku, określonym jako „ściśle tajny”, zanalizowano problem autochtoniczny. Jako głównych winowajców takowego, niekorzystnego z punktu widzenia władz państwowych stanu rzeczy, wskazano Niemców. Bo przecież - zdaniem autora analizy, posługującego się przedziwną polszczyzną - „Świadomość narodowa autochtonów polaków [pis. oryg. - GS] z punktu od 1945-o, a już wybitnie silnie stawała się negatywna przez pozostałych jeszcze na terenie niemców [pis. oryg. - G.S.], inteligencję, bowiem tacy szczególnie wykazywali chęć pozostania na miejscu [...]”. To oni, działając na szkodę polskich interesów mieli stosować propagandę kierowaną do ludności rodzimej i oto „Owa propaganda ostatnimi czasy przybrała dość poważne rozmiary. Potworzyły się jak gdyby dziwnym zbiegiem okoliczności, ośrodki całe $\mathrm{z}$ kąd [pis. oryg. - G.S.] promieniowała germańska propaganda" ${ }^{33}$. Dokument ten stanowi charakterystyczny przykład zarysowania celu - wroga, w którego przez następne lata - także i po „odwilży” 1956 roku, mierzyć będzie działalność komunistycznej policji politycznej. To wokół tej sprawy obracać się będą działania podejmowane wobec wszelkiej narodowej (a szczególnie niemieckiej) inności w bardzo represyjnych pierwszych latach 50 . XX wieku. By jednak ustawić sobie przed lufą dobrze rozpoznanego wroga, naleŻało - używając terminologii wojskowej - oczyścić przedpole. „Rozwiązano” zatem problem niezweryfikowanych Mazurów. Jak podał Andrzej Sakson, była to grupa licząca 20.067, traktowana jako pochodzenia etnicznego polskiego. Na tym terenie miało też przebywać pięć tysięcy rdzennych Niemców ${ }^{34}$.

W tym czasie i w takich okolicznościach wojewódzka bezpieka skupiła się na dwóch zagadnieniach. Po pierwsze na problemie szczegółowego sprawdzania i sumowania ilości niezweryfikowanych w powiatach do poziomu gminy. Nie wskazano nic nowego w przyjętej "metodologii” charakteryzowania problemu, gdy przyczyn trudności poszukiwano w zgermanizowaniu tzw. autochtonów polskich, niemieckiej - wewnętrznej i zewnętrznej (korespondencja pomiędzy Polską a zachodnimi strefami okupacyjnymi Niemiec) propagandzie straszącej karą niemiecką po kolejnej zmianie granicy; niepotrzebnym zwracaniu gospodarstw także niezweryfikowanym ${ }^{35}$. Po drugie na rozpracowywaniu spraw „po linii zagadnienia niemieckiego”. Które było organicznie powiązane ze sprawą niezweryfikowanych i utrzymywania się wśród ludności miejscowej postaw proniemieckich ${ }^{36}$.

33 IPN Bi, sygn. 087/163/Jacket, k. 0010-0014.

34 A. Sakson, Stosunki narodowościowe na Warmii i Mazurach w okresie stalinowskim, [w:] Ziemie Zachodnie i Pólnocne Polski w okresie stalinowskim, red. Cz. Osękkowski, Zielona Góra 1999, s. 169.

35 IPN Bi, sygn. 087/163/jacket, k. 0015-002.

36 W typowym sprawozdaniu z wykonanych czynności wymieniano kategorie spraw, którymi się zajmowano w odniesieniu do miejscowej ludności: współpraca z wywiadem niemieckim, podziemne organizacje niemieckie, agenci Abwehry, kanały przerzutowe, konfidenci i agenci gestapo i policji niemieckiej, współpraca z Niemcami, członkowie różnych organizacji hitlerowskich, szeptana propaganda, Volksdeutsche i uprzywilejowane narodowości, nadużycia służbowe, nielegalne przekraczanie granicy. Spraw takowych w okresie sprawoz- 
W dniu 25 stycznia 1949 roku na egzekutywie olsztyńskiego Komitetu Wojewódzkiego Polskiej Zjednoczonej Partii Robotniczej podjęto decyzję o wprowadzeniu ostrego kursu wobec opornych przyjęciu zadeklarowanego dobrodziejstwa polskiej narodowości i polskiego obywatelstwa. Sprawę poprowadził nowy (od grudnia 1948 roku) wojewoda olsztyński gen. Mieczysław Moczar, „wsławiony” kierowaniem w latach 1945-1948 Wojewódzkim Urzędem Bezpieczeństwa Publicznego w Łodzi. W Olsztynie w akcji przeciw Mazurom dopomagał mu szef miejscowego WUBP Henryk Palka. W ciągu lutego i marca, stosując także przymus fizyczny „przekonano” do zweryfikowania się około 19.000 ludzi. W poufnym raporcie odnośnego UBP z powiatu Mrągowo z lutego 1949 roku opisano „przebieg akcji weryfikacyjnej [...] i stosowane metody”. Tym razem obyło się bez stosowania przymusu bezpośredniego. Prowadzący akcję weryfikacyjną w znaczącej obecności kilku żołnierzy, przy wykorzystaniu agentury, prowokacji, demonstracyjnego wyprowadzania opornych przez żołnierzy i gróźb nakłonił opornych do poddania się procedurze weryfikacyjnej ${ }^{37}$.

Nie trzeba dodawać, iż takowa działalność jeszcze bardziej wzmocniła wśród miejscowej ludności proniemieckie nastroje ${ }^{38}$. O czym donosiły kolejne dokumenty powstałe w kręgu administracji ogólnej. Problem faktycznego stosunku do polskości i państwa polskiego tych ludzi nie zniknął przy pomocy administracyjnej i fizycznej perswazji. „Troskę” w tej sprawie przejawił wojewoda Moczar w połowie 1949 roku podczas Pierwszej Wojewódzkiej Konferencji PZPR w Olsztynie. Stwierdził, tak jakby to był proces naturalny, iż spośród około 100.000 miejscowych Mazurów i Warmiaków „pewien odsetek [...] przyjął obywatelstwo polskie dopiero przed kilku tygodniami”39. Jednak w tym czasie dalsze zauważanie problemu miało zupełnie inny wymiar, niż przed kilku laty. W nowym ogólnopolskim otoczeniu ideologicznym olsztyńska egzekutywa KW PZPR w lipcu 1949 roku zanalizowała błędy, „które opóźniły wciągnięcie biednego chłopstwa, robotników rolnych i miejskich miejscowego pochodzenia do walki klasowej przeciw kapitalistom, bogaczom wiejskim i spekulantom"40. Była to wyraźna konstatacja, konsumpcja nowych prądów. Państwo o jeszcze w tym czasie oficjalnej nazwie Rzeczpospolita Polska przystąpiło do przyspieszonej budowy socjalizmu o moskiewskim obliczu. Rozprawy z prawdziwym i wyimaginowanym wrogiem wszelkiej maści, w sytu-

\footnotetext{
dawczym prowadzono 2196. Przy czym skutecznie przeciwdziałano i rozpracowano 804 sprawy; zaniechano 593 sprawy. „Aresztowano [...] osób, oraz zapadło wyroków śmierci, więzienia dożywotniego i 15 lat więzienia” 668 osób. Por.: IPN Bi, sygn. 087/163/jacket, „sprawozdanie z dotychczasowej pracy t. j. od chwili powstania organizacji B. P. [Bezpieczeństwa Publicznego?] do 31.XII.1948 po linii zagadnienia niemieckiego”, k. 0023-0027.

37 IPN Bi, sygn. 087/163/jacket, k. 0028-0029.

38 G. Strauchold, Autochtoni polscy, s. 168.

39 Pierwsza Wojewódzka Konferencja P.Z.P.R. w Olsztynie, czerwiec 1949 [br. m. wyd.], s. 73.

40 APP, PZZ, sygn. 935, „Uchwała Egzekutywy KW PZPR w Olsztynie w sprawie ludności mazurskiej i warmińskiej z dn. 6 VII 1949 r.", k. 32.
} 
acji, gdy w istocie społeczeństwo było już ubezwłasnowolnione, odbywały się teraz w zamkniętych ścianach katowni Urzędów Bezpieczeństwa Publicznego, pomieszczeniach sądowych i więzieniach. Także i na Warmii i Mazurach nowy kurs zintensyfikował - utrzymywany nieprzerwanie wszak już od lata 1944 roku na ziemiach na zachód od Bugu - proces terroryzowania ludności miejscowej i napływowejej ${ }^{41}$.

Na kolejnej, drugiej konferencji KW PZPR w Olsztynie (1951 roku) - realizującej uchwałę Komitetu Centralnego z 1950 roku o roztoczeniu opieki nad ludnością miejscową - stwierdzono, w języku charakterystycznym dla epoki i równie kłamliwym, iż „Polska władza ludowa stanęła na stanowisku nadania ludności miejscowego pochodzenia pełnych praw obywatelskich, wciągnięcia mas autochtonicznych do odbudowy gospodarki zniszczonych terenów, do pracy nad umocnieniem państwa ludowego, do walki o wzrost dobrobytu mas pracujących. Mimo zniszczeń wywołanych okupacją w całym kraju, mimo trudności gospodarczych młodego organizmu państwowego, Rząd nasz przyszedł z natychmiastową wydatną pomocą gospodarcząZiemi Mazurskiej" "22. Kolejnym akcentem klasowym - bardzo groźnym dla osób nim dotkniętych - było oskarżenie na tym posiedzeniu przywódców ludności miejscowej, którzy wobec braku „czujności klasowej” partii komunistycznej (PPR) „będąc na stanowiskach udzielały pomocy ludności miejscowego pochodzenia w taki sposób, że w zasadzie pomogły, ale nie biednej ludności, lecz kułakom" ${ }^{33}$. Takowy osąd był skonstatowaniem trwających już co najmniej od 1948 roku represji wobec niezależnych od celów klasowych państwa aktywistów, weteranów polskiego mniejszościowego ruchu w Niemczech. Byli oni przeciwnikami marksistowsko-stalinowskiej wizji sprawiedliwości społecznej. Zostali więc, na odpowiednim „zakręcie”, odsunięci od wpływu na swoich ziomków. Także ta okoliczność - de facto - oddaliła możliwość pozyskania dla narodu i państwa polskiego jakiejś liczniejszej grupy miejscowej ludności.

Tymczasem, wbrew szumnym, publicznym deklaracjom, sytuacja w zaciszu gabinetów czynowników UBP nie była postrzegana tak tromtadracko. W zachowanej, niejawnej wówczas dokumentacji, wskazywano w marcu 1950 roku, że wśród zamieszkujących powiat olsztyński tzw. autochtonów „w dość dużej mierze znajdują się osoby podejrzane przez Urząd [...] jako wrogowie Polski Ludowej”. Utrzymywały się wśród nich tendencje do wyjazdu do Niemiec, co miało się przyczyniać do „zaniedbywania się w pracy na roli itp." ${ }^{44}$. W szeregu dalszych dokumentów opisano dość szczegółowo okoliczności wystąpień uznanych za wrogie wobec po-

${ }_{41}$ Por. na ten temat: B. Łukaszewicz, Życiorysy 1945-1956, Olsztyn 2008; idem, Represjonowani na Warmii i Mazurach 1945-1956, Olsztyn 2013.

42 IPN Bi, sygn. 087/163/jacket, k. 0030.

43 IPN Bi, sygn. 087/163, jacket, k. 0039.

44 IPN Bi, sygn. 087/156/jacket, k. 0045. 
lityki państwa. Niemal w każdej charakterystyce podkreślano istnienie niemieckiej propagandy docierającej z zagranicy do chętnych miejscowych uszu.

Z 1951 roku zachowało się szereg dokumentów opisujących rozpracowania obiektowe skierowane wobec osobników spośród ludności miejscowej. Inicjatywy te podejmowano wobec utrzymujących się nadal nastrojów niechętnych nowym porządkom (tak w wymiarze polsko-narodowym, jak i aktualno-klasowym). Generalnie takową „wrogą działalność” scharakteryzowano w raporcie z grudnia 1951 roku słowami: „Notowano opór elementu autochtonicznego inspirowanego przez wybitnie wrogie jednostki przy podpisywaniu pod Narodowym Plebiscytem Pokoju, Narodowej Pożyczce Rozwoju Sił Polski, w akcji wymianie waluty, w akcji przemeldunkowej, w ostatniej akcji „S” to jest planowy skup zboża, oddłużanie wsi itp." ${ }^{35}$. Biorąc pod uwagę, na czym w rzeczywistości polegała wspomniana „Narodowa Pożyczka..."; tzw. wymiana walut czy planowy skup zboża (akcje uderzające zresztą w całą ludność Polski) trudno się dziwić przeciwnym tym inicjatywom nastrojom. Ich potwierdzeniem był opór ludnóści rodzimej województwa olsztyńskiego wobec tẑw. paszportyzacji. Składała się ona z kolejnych etapów: przemeldowywania, fotografowania, ankietyzacji i wydawania dowodów osobistych. Jak napisal Zenon Romanow, paszportyzacja wzbudziła sprzeciw na wszystkich terenach zamieszkiwanych przez ludność rodzimą. W początkach marca 1951 roku przyjęcia kart meldunkowych, ewentualnie „złożenia podpisu pod zgłoszeniem miejsca zamieszkania” odmówiło w województwie olsztyńskim około 23.000 osób. Jak wskazał tenże badacz, motywy były różne. Obawiano się przyjęcia w ten sposób obywatelstwa sowieckiego, „włączenia do spółdzielni produkcyjnej, wyrzeczenia się katolicyzmu (na Warmii)", utrudnienia kontaktu z krewnymi w Niemczech, kary po powrocie państwowości niemieckiej ${ }^{46}$.

Nadal zatem, w kolejnym 1952 roku, kwestia autonomiczna przyprawiała olsztyńską bezpiekę o ból głowy. Liczbę ludności miejscowego pochodzenia (co ciekawe, ze sprawozdawczości zniknęli rdzenni Niemcy) liczono w województwie na 104.000 głów. Nie zakładano, że w Olsztyńskiem zamieszkiwać mogli bezsprzecznie narodowi Niemcy, a jedynie zniemczeni autochtoni. Przykładem takiego stosunku to kwestii narodowościowych była charakterystyka z marca 1952 roku: „Wśród [...] [autochtonów - G.S.] znajduje się około 2.000 osób bezwzględnie wrogo ustosunkowanych do Polski i przejawiających wrogą działalność. W większości z nich to ludzie, którzy byli związani aktywnie w poprzednim okresie z hitleryzmem. Elementy te $\mathrm{w}$ dobie obecnej nie mogą pogodzić się z rzeczywistością i polskością tut. terenów”" Należy podkreślić - co jest niemożliwe do precyzyjnego ustalenia

45 IPN Bi, sygn. 087/156/jacket, k. 0064.

46 Z. Romanow, Przebieg paszportyzacji ludności rodzimej ziem zachodnich i pólnocnych w latach 19511953, [w:] Ziemie Zachodnie i Pótnocne Polski w okresie, ss. 230-231.

47 IPN Bi, sygn. 087/163/jacket, k. 0050. 
- iż na postawy przynajmniej części tzw. autochtonów, demonstrujących swą niemieckość wpływała chęć wyjazdu do Niemiec. Chęć demonstrowana nie zawsze $\mathrm{w}$ zgodności $\mathrm{z}$ bezsprzecznie niemieckim poczuciem narodowym. W takich wypadkach - co zresztą było charakterystyczne dla innych terenów zamieszkiwanych przez ludność rodzimą - za intencjami emigracji kryło się dążenie do połączenie $\mathrm{z}$ rodziną, do osiągnięcia lepszego poziomu życia, do oderwania się od szarej, biednej i groźnej rzeczywistości egzystowania w kraju tzw. realnego socjalizmu.

Ciekawe konstatacje o sytuacji „na odcinku autochtonicznym” zawiera pismo skierowane w maju 1952 roku do szefa WUBP w Olsztynie. Warto przytoczyć odnośny ustęp dla możliwości jego zinterpretowania: „Na odcinku autochtonicznym notowana jest wroga działalność od chwili wyzwolenia tych terenów. Do roku 1951 działalność ta była w mniejszym stopniu notowana. Szczególnie jednak uwidacznia się od roku 1951-1952 r. wzmożenie wrogiej działalności w środowiskach autochtonicznych. [...] Działalność notowana w latach 1951-1952 wypływa przez inspirowanie, przez wrogie grupy i jednostki zam. na tutejszym terenie. Duży wpływ wywiera również obecna sytuacja między-narodowa [pis. oryg. - GS] i propaganda państw kapitalistycznych" ${ }^{48}$. Pomijając przyczyny natury zewnętrznej, przywoływane w wielu dokumentach powstałych w kręgach UBP, należy zwrócić uwagę na zupełne pominięcie sytuacji sprzed końca lat 40. XX wieku. Przecież nie była ona słodka. Autor analizy zachował się tak, jakby tamte sprawy i tamte lata w ogóle nie istniały. Jak gdyby odbyły się w zupełnie innym continuum, w przedklasowym okresie niewartym odnotowania. Być może wynikało to li tylko z niepodejmowania w okresie wcześniejszym szerszego rozpracowywania postaw ludności rodzimej pod kątem klasowym i pod kątem ich postaw proniemieckich. Może jednak chodziło nie tylko o kwestie klasowe i kwestie wypracowania przez MBP szczegółowej metodologii podejmowanych działań. Nie można też odrzucić wpływu na postawy tzw. autochtonów pogarszającego się klimatu ogólnego życia w stalinowskim protektoracie, uwidacznianym nie tylko przez represje i kolektywizację, ale także przez takie kampanie, jak paszportyzacja (dokumenty na ten temat pojawiały się i w okresie późniejszym, w 1953 roku $)^{49}$. Nie można też $\mathrm{w}$ interpretowaniu powyższego dokumentu odrzucić rytu charakterystycznego dla wszystkich „służb specjalnych” świata - dążenia do wykazywania w odnośnej sprawozdawczości niezbędności własnej egzystencji. Także konieczności inwestowania ze strony państwa w policję polityczną.

Przejawami aktywności olsztyńskiej bezpieki było monitorowanie wyjazdów do obu części Niemiec w ramach akcji łączenia rodzin; nieprzerwane tropienie po-

\footnotetext{
${ }^{48}$ IPN Bi, sygn. 087/163/jacket, k. 0094.

${ }_{49}$ Wśród zachowanej dokumentacji z tego okresu, „wyprodukowanej” w kręgach UBP, zwraca uwagę duża ilość szczegółowych tabel relacjonujących stan paszportyzacji i ankietyzacji. Widać, jaką uwagę przywiązywała policja polityczna do tych odgórnych inicjatyw.
} 
staw niemieckich i proniemieckich. Tutaj zwracano np. uwagę na osoby powracające zza Odry. Nadal uzupełniano dane na temat zamieszkujących województwo byłych członków NSDAP. Konkretnie groźnymi przykładami aktywności bezpieki były dokumenty relacjonujące rozpracowania autochtonicznych środowisk i aresztowania dokonywane wśród osób uznanych za prezentujących wrogie postawy. W tym za „rozsiewanie rewizjonistycznej propagandy” ${ }^{50}$. Termin „rewizjonizm” (niemiecki) zaczął wówczas coraz częściej pojawiać się w odnośnej dokumentacji. Zrobił on ogromną karierę, tak na niwie służb tajnych i specjalnych, jak i w oficjalnej, jawnej partyjno-państwowej propagandzie. Nie rozstaliśmy się z nim niemal do początku transformacji ustrojowej w Polsce w 1989 roku. Można było w tym jednym słowie zawrzeć wszystko, co na danym etapie byłoby przydatne dla wskazania palcem osobnika bądź środowiska oskarżanego o wyprzedaż interesów narodowych, ale i klasowych na rzecz Niemiec zachodnich. W szerszym zaś pojmowaniu tego słowa - na rzecz wrogiego socjalistycznemu „obozowi pokoju” świata zachodniego. W którym RFN była zaledwie jednym z elementów, za którym kryły się niecne zamiary Stanów Zjednoczonych Ameryki Północnej.

W 1953 roku zagadnienie „ludności miejscowego pochodzenia” nadal skupiato uwagę wojewódzkiego UBP. W dokumentach analizujących występujące wśród niej "tren dy" wskazywano niezmiennie na chęć emigrowania do Niemiec, odnotowywano (z podawaniem nazwisk i okoliczności, np. przez kontakty z kolejarzami czy marynarzami) nieprzerwane istnienie niemieckiej i proniemieckiej propagandy (w tym miejscowe reakcje na antykomunistyczne powstanie czerwcowe 1953 roku w Niemieckiej Republice Demokratycznej). Coraz częściej zjawiska te umieszczano w pojemnym worku na nazwie „rewizjonizm”. Zastępował on w odnośnej dokumentacji termin „niemiecki” i „proniemiecki”. Taki wytrych znakomicie ułatwiał życie funkcjonariuszom pochylającym się nad postawami ludności rodzimej. Postawami analizowanymi ze szczegółami, w odniesieniu do konkretnych osób, które pojawiały się w licznych sprawozdaniach w krótkich na ogól, kilkulinijkowych notatkach. Typu: „Głębocka Maria zam. Szczytno ul. Kajki Nr. 4 szerzy propagandę wojenną i wypowiada się, że w niedługim czasie na te tereny przyjdą Niemcy"s1. Jako formy działalności rewizjonistycznej wskazywano, na przykład, „wrogą propagandę, rozbijanie spółdzielni produkcyjnych, stosowanie terroru wobec aktywu w akcji skupu zboża i stawiany opór w wykonywaniu obowiązków wobec Państwa oraz w akcjach przeprowadzanych przez Rząd i Partię" ${ }^{2}$. Zatem wcale nie musiało chodzić o aktywizacje powiązane w jakikolwiek sposób z niemczyzną. Notabene tego typu opór (zagrożony represjami) miał wszak miejsce także na terenach, gdzie ludności rodzimej nie było.

50 IPN Bi, sygn. 087/156/jacket, k. 0099.

51 IPN Bi, sygn. 087/163/jacket, k. 0136.

52 IPN Bi, sygn. 087/163/jacket, k. 0165. 
Na odnotowywaniu przykładów wrogiej (rewizjonistycznej) działalności się nie kończyło. Zachował się dokument, który do „pracy operacyjnej po zagadnieniu rewizjonizmu" zaliczył zlikwidowanie nielegalnej organizacji, mającej się zajmować - tak to przynajmniej określono - akcjami „terrorystyczno-rabunkowymi”"53. Dla osiągania wymiernych wyników policja polityczna tworzyła sieć informatorów. Przykładowo we wrześniu 1953 roku w powiecie Barczewo liczyła ona dwunastu członków. W odnośnym wykazie podano ich kryptonimy, okoliczności werbunku, zajmowane stanowiska, przydatność operacyjną ${ }^{54}$.

Likwidowanie nielegalnych, uznawanych za wrogie grup (organizacji etc.) złożonych z tzw. autochtonów było szczegółowo opisywane w odnośnych sprawozdaniach. W konsekwencji następowały zatrzymania. W wykazie aresztowanych w województwie olsztyńskim w 1953 roku wymieniono 61 osób. Można było stracić wolność za - m.in.: dezinformację i wprowadzenie władzy w błąd, udzielenie pomocy bandzie, szpiegostwo, słuchanie wrogich audycji, propagandę, udzielenie pomocy w ucieczce za granicę, nielegalne posiadanie broni, działalność rewizjonistyczną, sabotaż, dawanie łapówek milicjantom ${ }^{55}$.

W kolejnym 1954 roku organa MBP nieprzerwanie produkowały liczne dokumenty świadczące obecnie - po ich ujawnieniu - o skali inwigilacji społeczeństwa. Także o intencji policji politycznej coraz szerszego zarzucania sieci na mieszkańców kraju. W tym wypadku na specyficznym terenie Warmii i Mazur UBP zainteresowane były - na przykład - byłymi członkami organizacji Hitler-Jugend, NSDAP, SA, SS, BDM (Związek Dziewcząt Niemieckich ${ }^{56}$ ), żandarmerii niemieckiej, oficerami i podoficerami Wehrmachtu, lotnikami Luftwaffe w powiecie Barczewo. Na podstawie tych zestawień tworzono wykazy „elementu podejrzanego”. W tymże powiecie w marcu 1954 roku na liście podejrzanych wymieniono 64 osoby, ze wskazaniem „o co [jest] podejrzany” i miejsca zamieszkiwania ${ }^{57}$. Z kategorii „podejrzany” można było, z pomocą sieci agenturalnej, przejść do kategorii „aresztowany”.

Wszelkie zaś aktywizacje (także i powyższe kwalifikacje), podlegające obserwacji i działaniom UBP umieszczane były w - nierzadko obszernych - opracowaniach poświęconych „rewizjonizmowi”. Rewizjonistą mógł zostać niemal każdy, za niemal każde działanie wykraczające poza bardzo wąskie ramy samodzielnego decydowania. Dokonywano aresztowań za tzw. pyskowanie i krytykowanie polskich porządków, za posiadanie "książek rewizjonistycznych” (w odnośnym dokumencie nie sprecyzowano, co to były za wydawnictwa), za pochwalanie poziomu życia

53 IPN Bi, sygn. 087/163/jacket, k. 0174.

54 IPN Bi, sygn. 087/156/jacket, k. 0141-0142.

55 IPN Bi, sygn. 087/163/jacket, k. 0172-0173.

56 Bund Deutscher Mädel.

57 IPN Bi, sygn. 087/156/jacket, k. 0156-0158. 
w Niemczech zachodnich, słuchanie niemieckich audycji radiowych, posiadanie rodziny za Łabą. Tu nasuwa się refleksja, że także na pozostałych terenach państwa polskiego, poza ziemiami zachodnimi i północnymi, można było zostać uznanym za „wroga ludu” w wyniku zaistnienia identycznych okoliczności. Jednakże w przypadku terenów zamieszkiwanych przez ludność rodzimą skala zjawiska była o wiele szersza i występowało ono w środowiskach zamieszkujących zwarcie w swoim własnym otoczeniu narodowościowo-kulturowym. Musiało to budzić czujność służb specjalnych.

Jako dowód ciągłego specjalizowania się policji politycznej, a także jej ofensywnego wychodzenia przeciw rewizjonistycznemu niebezpieczeństwu, może posłużyć wykaz niemieckich ośrodków - różnej zresztą proweniencji - „oddziałujących na ludność miejscowego pochodzenia Warmii i Mazur" ${ }^{38}$. Przy pomocy takowej listy można było - niejako z klucza - analizować strukturę nadchodzącej z Niemiec zachodnich korespondencji. Jak stwierdzono w ściśle tajnym opracowaniu z lutego 1954 roku korespondencję z Niemcami zachodnimi-miało utrzymywać ponad 30.000 osób. Każda z nich - naturalnie - stawała się podejrzana o rewizjonizm niemiecki i była odnotowywana w odnośnych spisach. Policja polityczna zainteresowana też była umieszczaniem w tychże ośrodkach swoich agentów.

Meldunki, sprawozdania, analizy, powstające również w kręgach policji politycznej, stanowiły podstawę dla centralnych władz partii komunistycznej w jej oglądzie sytuacji na ziemiach zachodnich i północnych. W zasobie KC PZPR w warszawskim Archiwum Akt Nowych zachował się, sygnowany przez Wydział Organizacyjny KC, dokument z marca 1954 roku pt. „Niektóre wnioski dla pracy wśród ludności autochtonicznej”. Zwrócono w nim uwagę - także w odniesieniu do województwa olsztyńskiego - na „poważne braki w pracy masowo-politycznej, w dziedzinie wysuwania kadr autochtonicznych, w polityce repolonizacyjnej ludności miejscowej, a zwłaszcza braki w dziedzinie prawidłowego reagowania na liczne skargi o dyskryminację ludności autochtonicznej”59. Był to język dawno nie widziany w dokumentach tyczących się ludności rodzimej. Wprost przywołujący zarzucone pod koniec lat czterdziestych metody. Sytuacja zaiste musiała być oceniana jako wysoce niekorzystna dla polityki państwa. Być może już odczuwano lekką bryzę nadciągającego „nowego” po śmierci Stalina (1953) i postępujących przemianach w Związku Sowieckim. Należy uzupełnić, iż w grudniu 1954 roku także w wyniku afery związanej z ucieczką na Zachód płk. Światły, Ministerstwo Bezpieczeństwa Publicznego zostało zastąpione Ministerstwem Spraw Wewnętrznych i Komitet do spraw Bezpieczeństwa Publicznego.

58 IPN Bi, sygn. 087/163/jacket, k. 0214.

59 AAN, Komitet Centralny Polskiej Zjednoczonej Partii Robotniczej, sygn. V-28, k. 220-223. 
Powyższe oceny i idące za nimi postulaty nie zmieniły jednakże generalnie wrogiego podejścia do wszelkich przejawów „rewizjonizmu”. Wszak trwała w najlepsze „zimna wojna”, granice Polski nie zostały - poza obozem państw satelickich Moskwy - na gruncie międzynarodowym uznane, w Bonn (ówczesnej stolicy Republiki Federalnej Niemiec) nie ukrywano, że demokratyczne Niemcy nie pogodziły się z utraceniem wielkich przestrzeni na wschodzie. Wszystko się jeszcze mogło zdarzyć... W efekcie w 1955 roku wyprodukowano w kręgach policji politycznej dużą ilość obszernych dokumentów analizujących na wszystkie możliwe strony „wrogą działalność rewizjonistyczną” na terenie województwa olsztyńskiego. Wśród nich za szczególnie symboliczne, obrazujące niepowodzenie polityki polskiej, uznawano dążenie do wyemigrowania do Niemiec (zachodnich).

Zjawisko to nadal daje się zauważyć w licznych dokumentach z 1956 roku Był to zresztą niemal nieprzerwany constans na terenie ziem włączonych do państwa polskiego w 1945 roku. Tzw. autochtoni polscy chcieli wyjeżdżać i wyjeżdżali w zmiennych liczebnością falach, podlegając labilnej polityce paszportowej państwa. Na co zreszztą wpływ miewała także sytuacja międzynarodowa Polski.

W dokumentacji proweniencji policji politycznej (wszak przekształcenia organizacyjne nie zlikwidowały tej służby) analizowano przyczyny wznoszącej się fali podań o zezwolenie na emigrację do Niemiec. Jako przyczyny wskazywano agitację płynącą z tzw. ziomkostw (organizacji przymusowo wysiedlonych z Polski w jej nowych granicach Niemców) działających w RFN. W tym kontekście snuto plany lokowania w tych organizacjach komunistycznej agentury. Tropiono zatem i umieszczano w odnośnych spisach osoby „aktywnie popierające wyjazdy do NRF przy pomocy wrogiej propagandy”. Nadal analizowano zjawisko „rewizjonizmu” wśród mieszkańców województwa olsztyńskiego. Tworzono zestawienia osób podejrzanych, w przeszłości w jakikolwiek sposób zaangażowanych w funkcjonowanie niemieckiego, nazistowskiego państwa. Fala podań o wyjazd była znacząca. Spośród zamieszkujących województwo we wrześniu 1956 roku 105.000 tzw. autochtonów (wśród nich zauważono „b. znikomy procent Niemców”) chęć wyjazdu przez złożenie odpowiednich dokumentów wyraziło 21.000 osób $^{60}$.

Był to czas, gdy w Polsce coraz mocniej wiał wiatr przemian. Do władzy powrócił Władysław Gomułka deklarujący (przynajmniej jeszcze w tym czasie) konieczność poprowadzenia całkiem innej polityki na ziemiach zachodnich i północnych. Było to wynikiem skonstatowania niepowodzenia na wielu frontach prowadzonej tam przez powojenną dekadę polityki ${ }^{61}$. Stopniowo uruchamiała się aktywność społeczna na tych terenach. Także i na Warmii i Mazurach ${ }^{62}$.

60 IPN Bi, sygn. 087/163/jacket, k. 0384.

${ }_{61}$ Por.: G. Strauchold, Powrót na „zaginiony” Zachód. Polityka Władysława Gomułki wobec Ziem Zachodnich i Pótnocnych $w$ latach 1956-1957, [w:] Klio viae et invia. Opuscula Marco Cetwiński dedicata, red. A. Odrzywolska-Kidawa, Warszawa 2010, ss. 449-463.

62 Por.: Październik 1956 na Ziemiach Zachodnich i Północnych, red. W. Wrzesiński, Wrocław 1997; Rok 1956 na Warmii i Mazurach. Wybór źródeł, wydał B. Łukaszewicz, Olsztyn 1998. 
To wówczas, $\mathrm{w}$ obliczu wielkiego poparcia społecznego, ale i nieustabilizowanej i nierozpoznawalnej sytuacji w Polsce Gomułka rzucił hasło wyborów bez skreśleń. Doszło do nich w styczniu 1957 roku. Warto, wychodząc poza cezurę końcową tego artykułu, spojrzeć, jak w nowej sytuacji, gdy zadeklarowano centralnie zmianę polityki prowadzonej wobec ludności rodzimej i utworzono Towarzystwo Rozwoju Ziem Zachodnich (zwalczające zresztą na wszystkie sposoby „rewizjonizm” niemiecki) kształtowały się postawy w województwie olsztyńskim. Otóż - zdaniem przedwyborczych meldunków sytuacyjnych - nadal utrzymywała się wysoka fala podań o wyjazd do Niemiec. Chyba tym bardziej utrwalona, że spodziewano się złagodzenia państwowej polityki paszportowej. Ale odnotowano także oddolne inicjatywy wskazujące na zaufanie do deklaracji polityków ${ }^{63}$. Aczkolwiek takowe przedsięwzięcia miały bardzo niewielki zasięg i zapewne przywoływane były w sprawozdawczości dla „pokrzepienia serc” władz nadrzędnych. Generalnie nastroje wśród masy tzw. autochtonów nie zmieniły się.

W ciągu powojennej dekady na przyłączonych do Rzeczypospolitej Polskiej terenach wschodniopruskich usiłowano wprowadzić w czyn wielotorową politykę. Przymusowemu wysiedlaniu na zachód miejscowej ludności niemieckiej towarzyszyła - odgórnie oficjalnie deklarowana - dążność do zachowania w Polsce miejscowej ludności pochodzenia etnicznego polskiego. Jednocześnie na te tereny ruszyła fala polskich osadników, poprzedzana rabunkowymi wyprawami zza przedwojennej granicy polsko-niemieckiej. Sytuacja powojennego rozgardiaszu, improwizacji, potwornych zniszczeń i powszechnego niedostatku mieszała się z już wówczas podejmowanymi działaniami dla skomunizowania państwa. Ta - nieprzebierająca w środkach działalność - powiązana była z nieskrywanym polskim nacjonalizmem o wybitnie ostrym (wówczas powszechnie zrozumiałym) ukierunkowaniu antyniemieckim. Zarazem konfrontowana z polskimi „porządkami” miejscowa ludność mazurska i warmińska - w dużym stopniu zgermanizowana - w masie nie czuła się dobrze w nowym państwie. W miarę upływu czasu coraz częściej ujawniała ona swe zamiary wyemigrowania do okupowanych Niemiec. Potem do RFN i NRD. Pod koniec lat 40-tych XX wieku uruchomiono w Polsce proces przyspieszonego budowania moskiewskiej odmiany socjalizmu. Od tego czasu osią działalności organów bezpieczeństwa nie było tylko tropienie wszelkich przejawów niemieckości. Teraz skupiono się także na kształtowaniu - także wśród ludności rodzimej - właściwych temu czasowi postaw klasowych. Zarazem, biorąc pod uwagę narastającą konfrontację na linii Wschód - Zachód, którego przedprożem była demokratyczna

63 Por.: IPN Bi, sygn. 087/163/jacket, k. 0421-0424; IPN Bi, sygn. 087/163/jacket, k. 0425-0428; IPN Bi, sygn. 087/163/jacket, k. 0434-0436. 
Republika Federalna Niemiec, bezpieka realizowała drugi najważniejszy ryt swej aktywności w województwie olsztyńskim. Była nim walka z szeroko pojmowanym „rewizjonizmem” niemieckim. Pod którym to pojęciem lokowano najprzeróżniejsze zachowania tzw. autochtonów. Postrzegane jako nieprzychylne, albo nawet wprost wrogie komunistycznym władzom. Po upłynięciu powojennej dekady okazało się, że ani nie zamieniono tzw. autochtonów w świadomych, socjalistycznych robotników i chłopów, ani nie wyeliminowano wśród nich zachowań „rewizjonistycznych". Miarą polskiej klęski były nieustające tendencje wyjazdowe. Ci - bardzo nieliczni, którzy po półwieczu ostali się na ziemi ojców, stali się w demokratyzującej się Polsce podstawą lokalnej mniejszości niemieckiej ${ }^{64}$.

Grzegorz Strauchold, Die Maßnahmen des Sicherheitsdienstes in Bezug auf die deutsche Bevölkerung und die sog. polnischen Autochthonen in Ermland und Masuren in den Jahren 1945-1956

Zusammenfassung

Im Beitrag wurden die Maßnahmen der kommunistischen politischen Polizei in Bezug auf ehemalige Bürger Deutschlands beschrieben, die in ihren Wohngebieten dieses Teils Ostpreußens geblieben sind, der Polen angeschlossen wurde. Polnische Kommunisten führten bis Ende der 40er Jahre des 20. Jh. eine Politik, deren Ziel war, unter Bewohnern Polens die deutschstämmige Bevölkerung gänzlich zu eliminieren. Seit Ende der 40er Jahre des 20. Jh. wurde versucht, unter der hier gebliebenen deutschen Bevölkerung, den ehemaligen Bürgern Deutschlands, die Personen, die mit der deutschen Nation verbunden waren und diejenigen, die 1945 entstandene neue polnisch-deutsche Grenze infrage stellten, tatkräftig zu tilgen. Die kommunistische politische Polizei interessierte sich auch für Leute (und ihre Ansichten), die gegenüber dem in Polen einzuführenden kommunistischen Systems kritisch waren.

Übersetzt von Alina Kuzborska

Grzegorz Strauchold, Activities of the security services against the German population and the so-called Polish autochthones in Warmia and Mazury in the years 1945-1956

Summary

The article describes the activities of the Communist political police against former German citizens who remained in their places of residence in the part of East Prussia incorporated into Poland. Polish communists until the end of the 1940s were conducting a policy that would eliminate German nationality from the inhabitants of Poland. From the end of the 1940s there was a concerted attempt to eliminate anyone with German nationality and those questioning the new Polish-German border that was created in 1945 among the remnants of the German citizenry. The Communist political police were also interested in people (and their views) who showed a critical attitude toward the Communist regime introduced into Poland.

Translated by Aleksander Pluskowski

Prof. dr hab. Grzegorz Strauchold

Instytut Historii Uniwersytetu Wrocławskiego

grzegorz.strauchold@uwr.edu.pl

${ }^{64}$ Por.: B. Domagała, Mniejszość niemiecka na Warmii i Mazurach. Rodowód kulturowy, organizacja, tożsamość, Olsztyn 1996. 


\section{Źródła archiwalne}

Archiwum Akt Nowych, Komitet Centralny Polskiej Zjednoczonej Partii Robotniczej

Archiwum Akt Nowych, Ministerstwo Administracji Publicznej.

Archiwum Akt Nowych, Ministerstwo Informacji i Propagandy.

Archiwum Akt Nowych, Ministerstwo Ziem Odzyskanych.

Archiwum Państwowe Poznań, Polski Związek Zachodni.

Instytut Pamięci Narodowej, Oddział Białystok.

\section{Źródła drukowane}

Niemcy $w$ Polsce 1945-1950

2000 Niemcy w Polsce 1945-1950. Wybór dokumentów, red. W. Borodziej, H. Lemberg, t. I, Władze i instytucje centralne. Województwo olsztyńskie, wyb. i oprac. W. Borodziej, C. Kraft, Warszawa.

Rok 1956 na Warmii i Mazurach

1998 Rok 1956 na Warmii i Mazurach. Wybór źródeł, wyd. B. Łukaszewicz, Olsztyn.

\section{Opracowania}

Bańka Tomasz

1997 Ziemie odzyskane w polityce Polskiego Stronnictwa Ludowego w latach 1945-1947, [w:] Władze komunistyczne wobec Ziem Odzyskanych po II wojnie światowej, red. S. Łach, Słupsk, ss. 113-121.

Domagała Bożena

1996 Mniejszość niemiecka na Warmii i Mazurach. Rodowód kulturowy, organizacja, tożsamość, Olsztyn.

Domke Radosław

2010 Ziemie Zachodnie i Północne Polski w propagandzie lat 1945-1948, Zielona Góra.

Hejger Maciej

2008 Przekształcenia narodowościowe na Ziemiach Zachodnich i Północnych Polski w latach 1945-1949, Słupsk.

Kopiczko Andrzej

1996 Kościół warmiński a polityka wyznaniowa po II wojnie światowej, Olsztyn.

Kossert Andreas

2004 Mazury. Zapomniane południe Prus Wschodnich, Warszawa.

2009 Prusy Wschodnie. Historia i mit, Warszawa.

Krysiak Dominik

2013 Warmia i Mazury w latach 1945-1950. Kształtowanie się stosunków politycznych i narodowościowych, Olsztyn-Białystok.

Łukaszewicz Bohdan

1996 PSL na Warmii i Mazurach w latach 1945-1947, Warszawa.

2008 Życiorysy 1945-1956, Olsztyn.

2013 Represjonowani na Warmii i Mazurach 1945-1956, Olsztyn.

Mazur Zbigniew

2001 O adaptacji niemieckiego dziedzictwa kulturowego na Ziemiach Zachodnich i Północnych, Poznań.

Michalak Ryszard

2000 Luteranie i metodyści na Mazurach 1945-1957. Wybór materiałów, Kraków.

2002 Kościoły protestanckie i władze partyjno-państwowe w Polsce (1945-1956), Warszawa. 
Nitschke Bernadetta

1999 Wysiedlenie ludności niemieckiej z Polski w latach 1945-1959, Zielona Góra.

Październik 1956

1997 Październik 1956 na Ziemiach Zachodnich i Północnych, red. W. Wrzesiński, Wrocław.

Pierwsza Wojewódzka Konferencja P.Z.P.R.

Pierwsza Wojewódzka Konferencja P.Z.P.R. w Olsztynie, czerwiec 1949 [br. m. wyd.], s. 73.

Polacy wobec Niemców

1993 Polacy wobec Niemców. Z dziejów kultury politycznej Polski, red. A. Wolff-Powęska, Poznań.

Romanow Zenon

1999a Polityka władz polskich wobec ludności rodzimej Ziem Zachodnich i Północnych w latach 1945-1960, Słupsk.

1999b Przebieg paszportyzacji ludności rodzimej ziem zachodnich i północnych $w$ latach 1951-1953, [w:] Ziemie Zachodnie i Pótnocne Polski w okresie Ziemie Zachodnie i Pótnocne Polski w okresie stalinowskim, red. Cz. Osękowski, Zielona Góra, ss. 230-231.

Sakson Andrzej

1990 Mazurzy - społeczność pogranicza, Poznań.

1998 Stosunki narodowościowe na Warmii i Mazurach 1945-1997, Poznań.

1999 Stosunki narodowościowe na Warmii i Mazurach w okresie stalinowskim, [w:] Ziemie Zachodnie i Pótnocne Polski w okresie stalinowskim, red. Czesław Osękowski, Zielona Góra.-

2011 Od Kłajpedy do Olsztyna. Współczesni mieszkańcy byłych Prus wschodnich: Kraj Klajpedzki, Obwód Kaliningradzki, Warmia i Mazury, Poznań.

Strauchold Grzegorz

1995 Polska ludność rodzima ziem zachodnich i pótnocnych. Opinie nie tylko publiczne lata 1944-1948, Olsztyn.

2000 Trudne dziedzictwo. Wokół Kongresu Autochtonów w Warszawie (1946), [w:] Wspólne dziedzictwo? Ze studiów nad stosunkiem do spuścizny kulturowej na Ziemiach Zachodnich i Pólnocnych, red. Z. Mazur, Poznań, ss. 483-514.

2001a Autochtoni polscy, niemieccy, czy... Od nacjonalizmu do komunizmu (1945-1949), Toruń.

2001b Ludność rodzima pod „opiekq” cenzury (1945-1948). Przyczynek do polityki informacyjnej lat 40., [w:] Wrocławskie Studia z Historii Najnowszej, t. VIII, red. Wojciech Wrzesiński, Wrocław, ss. 277-286.

2003 Myśl zachodnia i jej realizacja w Polsce Ludowej w latach 1945-1957, Toruń.

2010 Powrót na „zaginiony” Zachód. Polityka Władysława Gomułki wobec Ziem Zachodnich i Północnych w latach 1956-1957, [w:] Klio viae et invia. Opuscula Marco Cetwiński dedicata, red. Anna Odrzywolska-Kidawa, Warszawa, ss. 449-463.

2011 Swoi czy obcy? Kwestia ludności autochtonicznej w pierwszych latach po zakończeniu II wojny światowej, [w:] Internacjonalizm czy...? Działania organów bezpieczeństwa państw komunistycznych wobec mniejszości narodowych (1944-1989), red. J. Hytrek-Hryciuk, G. Strauchold, J. Syrnyk, Warszawa-Wrocław, ss. 77-91.

2012 Zmierzch. Desinteressement komunistów wobec kwestii tzw. autochtonów polskich w końcu lat 40. XX w., Athenaeum. Polskie Studia Politologiczne, vol. 33, ss. 50-63.

2013 Od Bieruta do Gierka. Ziemie zachodnie i północne w optyce komunistycznej propagandy, [w:] Nad Odra i Bałtykiem. Myśl zachodnia: ludzie - koncepcje - realizacja do 1989 r., red. M. Semczyszyn, T. Sikorski, A Wątor, Szczecin, ss. 471-488.

2014 „Temperowanie” niepokornych. Komuniści wobec postaw wyborczych tzw. autochtonów polskich w obliczu referendum (1946) $i$ wyborów do sejmu Ustawodawczego (1947), [w:] Wybory i referenda w PRL, red. S. Ligarski, M. Siedziako, Szczecin, ss. 581-595.

Traba Robert

2003 Kraina tysiąca granic. Szkice o historii i pamięci, Olsztyn.

Trosiak Cezary

2013 Dyskusja na temat założeń i przebiegu polityki osadniczej na tzw. ziemiach odzyskanych w okresie II wojny światowej i bezpośrednio po jej zakończeniu, [w:] Nad Odrą i Bałtykiem. Myśl zachodnia: ludzie - koncepcje - realizacja do 1989 r., red. M. Semczyszyn, T. Sikorski, A. Wątor, Szczecin, ss. 497-508. 
Tyszkiewicz Jakub

1997 Sto wielkich dni Wrocławia. Wystawa Ziem Odzyskanych we Wrocławiu a propaganda polityczna ziem zachodnich i pótnocnych w latach 1945-1948, Wrocław.

Wspólne dziedzictwo?

2000 Wspólne dziedzictwo? Ze studiów nad stosunkiem do spuścizny kulturowej na Ziemiach Zachodnich i Pólnocnych, red. Z. Mazur, Poznań.

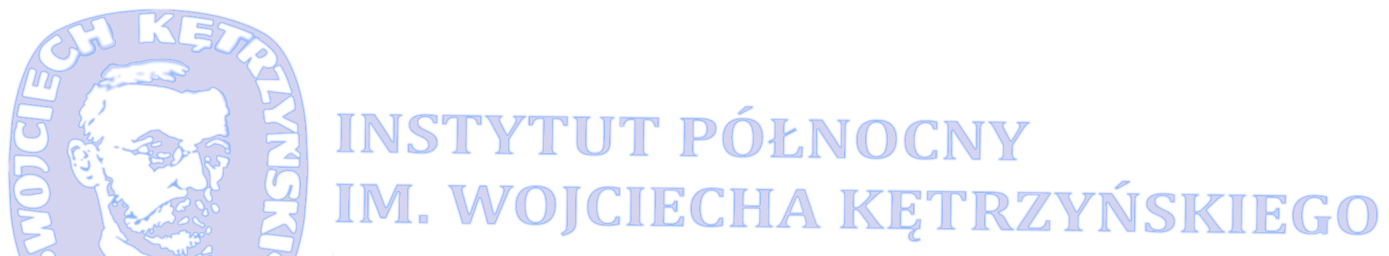

